\title{
Effect of irrigation with nutrient solutions mixed with treated wastewater on Asiatic lily 'Brunello' grown in a closed soilless culture
}

\author{
Khalid M. AL-GHAWANMEH ${ }^{1}$, Nabeel M. BANI-HANI ${ }^{2}$, Ahmed A. AL-HAMMOURI**3 ${ }^{3}$, Nabila S. KARAM ${ }^{4}$
}

Received March 14, 2016; accepted November 18, 2016.

Delo je prispelo 14. marca 2016, sprejeto 18. novembra 2016.

\begin{abstract}
A plastic greenhouse study was implemented to evaluate the potential use of treated wastewater for irrigation of Asiatic lily 'Brunello' grown in zeolite. Plants received the following treatments: a nutrient solution $(\mathrm{N})$ alone, $(\mathrm{N})$ mixed with treated wastewater $(\mathrm{W})$ at rates of $3 \mathrm{~N}: 1 \mathrm{~W}, 1 \mathrm{~N}: 1 \mathrm{~W}$ and $1 \mathrm{~N}: 3 \mathrm{~W}$ respectively. A closed system was used in which the drain solution was circulated for several days until its electrical conductivity reached $2.3 \mathrm{dS} \mathrm{m}^{-1}$, after which fresh irrigation solutions were used to start a second cycle of circulation. The results indicated that plants irrigated with $(\mathrm{N})$ or $3 \mathrm{~N}: 1 \mathrm{~W}$ solution had the longest stems (34.4 and $36.2 \mathrm{~cm})$ respectively, peduncles and buds (about $4.5 \mathrm{~cm}$ ), and the greatest shoot $(3.4$ and $3.8 \mathrm{~cm}$ ) and bud mass (14.95 and $17.6 \mathrm{~g}$ ) respectively. Plants irrigated with $1 \mathrm{~N}: 3 \mathrm{~W}$ solution had the highest dry mass tissue content of $\mathrm{K}\left(3.06 \mathrm{~g} \mathrm{~kg}^{-1}\right)$ and $\mathrm{B}$ $\left(35.5 \mathrm{mg} \mathrm{kg}^{-1}\right.$ ). Plants irrigated with $1 \mathrm{~N}: 1 \mathrm{~W}$ or $1 \mathrm{~N}: 3 \mathrm{~W}$ were inferior to other plants. It can be concluded that $1 \mathrm{~N}: 3 \mathrm{~W}$ mixture may be used for production of high quality cut flowers of lily. Moreover, it is expected to save 3.4 litres $\mathrm{m}^{-2}$ of a nutrient solution and 1850,347 and $1870 \mathrm{mg} \mathrm{m}^{-2}$ day $^{-1}$ for $\mathrm{N}, \mathrm{P}$, and $\mathrm{K}$ respectively.
\end{abstract}

Key words: Lilium; irrigation; wastewater; zeolite; nutrient solution; drainage solution recycling; JUST

\section{IZVLEČEK}

\section{UČINKI NAMAKANJA Z MEŠANICO HRANILNE RAZTOPINE IN ODPADNE VODE NA AZIJSKO LILIJO 'Brunello' GOJENO V ZAPRTEM BREZTALNEM SISTEMU}

$\mathrm{V}$ raziskavi, izvedeni $\mathrm{v}$ plastenjaku, je bila ovrednotena potencialna uporaba odpadne vode za gojenje azijskih lilij 'Brunello' gojenih na zeolitu. Opravljena so bila naslednja obravnavanja: uporaba čiste hranilne raztopin $(\mathrm{N})$, mešanica hranilne raztopine $(\mathrm{N}) \mathrm{z}$ odpadno vodo (W) $\mathrm{v}$ razmerjih $3 \mathrm{~N}: 1 \mathrm{~W}, 1 \mathrm{~N}: 1 \mathrm{~W}$ in $1 \mathrm{~N}: 3 \mathrm{~W}$. Uporabljen je bil zaprt sistem, $\mathrm{v}$ katerem je raztopina krožila več dni, dokler njena električna prevodnost ni dosegla $2,3 \mathrm{dS} \mathrm{m}^{-1}$, potem je bila uporabljena sveža raztopina za začetek drugega kroga poskusa. Rezultati so pokazali, da so imele rastline, ki so bile namakane samo s hranilno raztopino $(\mathrm{N})$ ali $\mathrm{z}$ mešanico $3 \mathrm{~N}: 1 \mathrm{~W}$, najdaljša stebla $(34,4$ in $36,2 \mathrm{~cm}$ ), cvetne peclje in popke (okrog $4,5 \mathrm{~cm}$ ), največjo maso poganjkov $(3,4$ in $3,8 \mathrm{~cm})$ in popkov $(14,95$ in $17,6 \mathrm{~g})$. Rastline, ki so bile zalivane $\mathrm{z}$ raztopino $1 \mathrm{~N}: 3 \mathrm{~W}$, so imele največjo suho maso tkiv, največjo vsebnost $\mathrm{K}$ $\left(3,06 \mathrm{~g} \mathrm{~kg}^{-1}\right)$ in $\mathrm{B}\left(35,5 \mathrm{mg} \mathrm{kg} \mathrm{kg}^{-1}\right)$. Rastline, ki so bile namakane $\mathrm{z}$ mešanicami raztopin $1 \mathrm{~N}: 1 \mathrm{~W}$ in $1 \mathrm{~N}: 3 \mathrm{~W}$ so bile slabše v primerjavi s prejšnjimi. Zaključili bi lahko, da bi za pridelavo zelo kvalitetnega rezanega cvetja azijskih lilij lahko uporabili mešanico raztopin $1 \mathrm{~N}: 3 \mathrm{~W}$ in s tem prihranili $3,41 \mathrm{~m}^{-}$ ${ }^{2}$ hranilne raztopine in 1850,347 in $1870 \mathrm{mg} \mathrm{m}^{-2} \mathrm{dan}^{-1} \mathrm{~N}, \mathrm{P}$ in K.

Ključne besede: Lilium; namakanje; odpadna voda; zeolit; hranilna raztopina; recikliranje raztopine; JUST

\footnotetext{
1 MercyCorps, P.O. Box 830684, Amman 11183, Jordan. E-mail: kghawanmeh@ jo.mercycorps.org

2 The National Center for Agricultural Research and Extension, Amman, Jordan. E-mail: nabeelbanihani@yahoo.com

3 Corresponding author. Department of Land Management \& Environment, Faculty of Natural Resources \& Environment, Hashemite University, P.O. Box 150459, Zarqa 13115, Jordan. E-mail: hammouri@hu.edu.jo. Cell phone: (+962791444593).

4 Department of Plant Production, Faculty of Agriculture, Jordan University of Science and Technology (JUST), P.O. Box 3030, Irbid 22110, Jordan. E-mail: karam@just.edu.jo
}

This study was funded by The Deanship of Scientific Research at JUST. 


\section{INTRODUCTION}

Closed soilless culture is used to conserve water, increase fertilizer use efficiency, and reduce nutrient leaching into the environment. However, continual use of the drain solution in closed cultures may result in increased salinity in the circulating solution (Baas et al., 1995; Karam and Al-Daood, 2005; Sonneveld and Van der Burg 1991; Sonneveld et al., 1999) and nutritional imbalances (Savvas, 2001). So, management of agricultural water becomes very important (Maryam et al., 2015; Mohammad, 2012a; Mohammad, 2012b; Stavros et al., 2015). To reduce consumption of potable water in agriculture, treated wastewater has been used as an alternative source of irrigation water which may also compensate for partial fertilizer requirements (Karam et al.,2009) and provide adequate amount of nutrients (Khan et al., 2009) for some plants. Treated wastewater has shown to have no adverse effect on rose (Rosa hybrida) (Bernstein et al., 2006) and to improve quality and yield of ornamental plants including croton (Codiaeum variegatum Blume) (Karam et al., 2006), lily (Lilium 'Aziatische Group ') (Safi et al., 2007a) and gerbera (Gerbera jamesonii Bolus ex Hooker f.) (Damasceno et al., 2010). However, treated wastewater was found to increase salinity of soil (Hussain et al., 2002; Safi et al., 2007b).

Salinity affects plant growth through osmotic potential of the soil solution, nutritional imbalance and/or specific ion effects (Shannon, 1998). Nutritional imbalances are related to nutrient availability, competitive uptake, and transport or partitioning within the plant (Grattan and Grieve, 1994). In fact, salinity was reported to reduce growth and yield of cut flowers (Baas et al., 1995; Sonneveld and Van der Burg, 1991) including lily
(Daood and Karam, 2007; Karam and Al-Daood, 2005; Morgan, 2006; Sonneveld et al., 1999).

To overcome salinity issues, zeolites, a microporous aluminosilicate mineral, has been commonly used as growing medium in plant production. Zeolites have the ability to mitigate the salt damage of plants by exchanging $\mathrm{Na}$ in water for Ca of the zeolite (Yasuda et al., 1998). So, they may be used when saline water is used for irrigation. Occlusion of $\mathrm{NaCl}$ from aqueous solutions occurs in zeolite since the surface conductivity of zeolite increases in salt solutions due to the ion pairs of salt adsorbed onto the hydroxyl groups of the zeolite surface (Breck, 1974), consequently, preventing excessive $\mathrm{Na}$ uptake by the plant and reducing its toxicity (Qian et al., 2001). Incorporation of zeolitic tuff into peat-perlite was recommended to reduce substrate EC and to offset the adverse effect of salinity associated with treated wastewater, rendering the substrate more favourable for growth of croton (Karam et al., 2006; Karam et al., 2009).

Closed soilless culture was reported to reduce water and fertilizer use for Asiatic lily 'Zsa Zsa' in zeollitic tuff without affecting plant performance (Karam and Al-Daood, 2005). Treated wastewater has also been used for cut flowers in open soilless culture (Safi et al., 2007b) and in soil (Safi et al., 2005; Safi et al., 2007b). However, there are no documented studies on irrigation of hybrid lily with treated wastewater in a closed soilless culture. Using treated wastewater as an alternative source of irrigation water would minimize the use of fresh water. The objective of the current study is to evaluate the potential use of treated wastewater for irrigation of Asiatic lily 'Brunello' in a closed soilless culture.

\section{MATERIALS AND METHODS}

The experiment was conducted in Jordan University of Science and Technology-Jordan (JUST), inside a plastic greenhouse with average daily temperature of $25 \pm 3{ }^{\circ} \mathrm{C}$, relative humidity (RH) of $35 \%$, photosynthetic photon flux density (PPFD) of $97 \mu \mathrm{mol} \mathrm{m}^{-2} \mathrm{~s}^{-1}$, and natural photoperiod.
Sixteen growing beds $(3 \mathrm{~m}$ length $\mathrm{x} 0.30 \mathrm{~m}$ width $\mathrm{x}$ $0.25 \mathrm{~m}$ depth each) were constructed from polyethylene $(1000 \mu)$ and were placed on the ground at a slope of 1-2\%. A screen filter was fitted at the end of each bed to prevent passage of the substrate particles out of the bed. Each bed was filled with two layers of black zeolitic tuff, which 
consisted of $5 \%$ zeolite minerals, $70 \%$ basalt volcanic glass and $25 \%$ silicate minerals, with 15 meq $100 \mathrm{~g}^{-1}$ CEC, 6.8-7.2 $\mathrm{pH}$ and 0.8-1.2 $\mathrm{dS} \mathrm{m}^{-}$

${ }^{1}$ EC. The lower layer $(5 \mathrm{~cm}$ depth) consisted of coarse particles $(8-16 \mathrm{~mm})$, which contained (\%) $1.0 \mathrm{NH}_{4}, 1.5 \mathrm{P}_{2} \mathrm{O}_{5}, 2.0 \mathrm{~K}_{2} \mathrm{O}, 7.0 \mathrm{CaO}, 5.0 \mathrm{MgO}$, $1.0 \quad \mathrm{SO}_{3}, 0.1 \quad \mathrm{Na}_{2} \mathrm{O}, 14.1 \quad \mathrm{Al}_{2} \mathrm{O}_{3}, 43.3 \quad \mathrm{SiO}_{2}, 2.0$ $\mathrm{TiO}_{2}, 12.0 \mathrm{H}_{3} \mathrm{O}^{+}, 9.9 \mathrm{FeO}, 0.9 \mathrm{MnO}$ and (ppm) 150 $\mathrm{Zn}, 200 \mathrm{Cu}, 100 \mathrm{Mo}, 40 \mathrm{~B}$ and $0.2 \mathrm{As}$. The upper layer $(15 \mathrm{~cm}$ depth) consisted of fine particles $(<3 \mathrm{~mm})$, which contained (\%) $0.31 \quad \mathrm{P}_{2} \mathrm{O}_{5}$, $0.81 \mathrm{~K}_{2} \mathrm{O}, 11.44 \mathrm{CaO}, 7.08 \mathrm{MgO}, 0.8 \mathrm{Na}_{2} \mathrm{O}$, $13.17 \mathrm{Al}_{2} \mathrm{O}_{3}, 46.98 \mathrm{SiO}_{2}, 1.95 \mathrm{TiO}_{2}, 12.64 \mathrm{Fe}_{2} \mathrm{O}_{3}$ and $0.15 \mathrm{MnO}$. One layer of plastic mesh $(10 \mathrm{x}$ $10 \mathrm{~cm}$ ) was laid on the bed surface before planting to support the plants and prevent lodging.

Asiatic lily 'Brunello' bulbs (12-14 cm circumference) were planted $10 \mathrm{~cm}$ deep in each growing bed at $25 \times 25 \mathrm{~cm}$ planting space. The bulbs were irrigated with tap water for two weeks before starting the treatments. The experiment was conducted in a completely randomized design with four replicates (growing beds) per treatment and 24 plants per bed.

A nutrient solution $(\mathrm{N})$ was prepared by diluting 21 of each of three stock nutrient solutions in 4001 tap water. The first stock solution contained (per

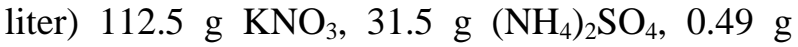
$\mathrm{ZnSO}_{4}, 0.48 \mathrm{~g} \mathrm{MnCl}_{2}$ and $0.035 \mathrm{~g} \mathrm{CuSO}_{4}$, the second contained $112.5 \mathrm{~g}_{\mathrm{KNO}_{3}}$ and $6.1 \mathrm{~g}$ $\mathrm{Fe}\left(\mathrm{NO}_{3}\right)_{3} .9 \mathrm{H}_{2} \mathrm{O}$ and the third contained $30.12 \mathrm{ml}$ $\mathrm{H}_{3} \mathrm{PO}_{4}$ and $116.65 \mathrm{~g} \mathrm{Ca}\left(\mathrm{NO}_{3}\right)_{2}$. The treatments consisted of four irrigation solutions: the nutrient solution $(\mathrm{N})$, singly or mixed with secondary treated wastewater $(\mathrm{W})$ at rates of $3 \mathrm{~N}: 1 \mathrm{~W}, 1 \mathrm{~N}: 1 \mathrm{~W}$ or $1 \mathrm{~N}: 3 \mathrm{~W}$. Tap water had EC of $1.27 \mathrm{dS} \mathrm{m}^{-1}, \mathrm{pH}$ 8.2 and treated wastewater had EC of $2.48 \mathrm{dS} \mathrm{m}^{-1}$ and $\mathrm{pH}$ 7.9. Chemical analysis of the irrigation solutions is presented in Table 1 .

The irrigation solutions were injected separately using a submerged pump in 4001 tank per treatment into a GR drip irrigation system with 8 drippers per growing bed and $4 \mathrm{l} \mathrm{h}^{-1}$ dripper discharge. The plants were automatically irrigated with the irrigation solutions three times a day at $8.00,12.00$ and 18.00 o'clock for $15 \mathrm{~min}$ each. At the end of the day, the drain solutions from the four replicate beds of each treatment were collected, mixed and the volume was measured. The drain solution was then returned to the corresponding tank to be mixed with the irrigation solution to form the supply solution which was circulated the next day. The EC and $\mathrm{pH}$ of the supply and drain solutions were measured once daily using a manual EC meter (Omega TDH5031, USA) and pH meter (Omega PHH-5012, USA). Irrigation scheduling and drainage management were repeated daily until the drain solution reached a threshold EC $\left(2.3 \mathrm{dS} \mathrm{m}^{-1}\right)$, after which the supply solution in the tank was replaced with a fresh irrigation solution to start a new cycle of circulation. This strategy was adopted until the end of the experiment. The volume of the circulating solution supplied to each treatment / day $/ \mathrm{m}^{2}$ was calculated as follows: [4 growing beds $* 8$ drippers $* 41 \mathrm{~h}^{-1}$ dripper discharge $* 45$ min irrigation duration] / [4 growing beds * $3 \mathrm{~m}$ long $* 0.3 \mathrm{~m}$ width] $=26.71$.

At the end of the experiment (40 days after planting), the plants were harvested when the first flower was fully coloured, but not yet open. The plants were dug out and the tuff particles around the roots were carefully removed keeping the root system intact. Data were recorded on stem length (from bulb tip to peduncle base) and diameter, leaf number, root length (from bulb base to the longest root tip), shoot (stem and leaves) and root fresh and dry (oven dried at $70{ }^{\circ} \mathrm{C}$ for $48 \mathrm{~h}$ ) mass, peduncle length and bud number, length and mass. Tissue analysis was performed for determination of concentrations of macro, micro and heavy metal elements. 
Table 1: Chemical analysis of the irrigation solutions prepared from a nutrient solution $(\mathrm{N})$, singly or mixed with treated wastewater $(\mathrm{W})$ at $3: 1,1: 1$ or $1: 3$

\begin{tabular}{l|llll}
\hline \multirow{2}{*}{ Variables } & \multicolumn{4}{|c}{ Irrigation solution treatments } \\
\cline { 2 - 5 } & $\mathrm{N}$ & $3 \mathrm{~N}: 1 \mathrm{~W}$ & $1 \mathrm{~N}: 1 \mathrm{~W}$ & $1 \mathrm{~N}: 3 \mathrm{~W}$ \\
\hline $\mathrm{EC}\left(\mathrm{ds} \mathrm{m}^{-1}\right)$ & 1.65 & 1.73 & 1.91 & 2.12 \\
$\mathrm{pH}$ & 6.58 & 7.72 & 7.92 & 8.01 \\
$\mathrm{~N}(\mathrm{ppm})$ & 184 & 144 & 105 & 65 \\
$\mathrm{P}(\mathrm{ppm})$ & 34.5 & 26.6 & 18.7 & 10.8 \\
$\mathrm{~K}(\mathrm{ppm})$ & 186 & 154 & 100 & 79 \\
$\mathrm{Ca}(\mathrm{ppm})$ & 126 & 113 & 99 & 86 \\
$\mathrm{Mg}(\mathrm{ppm})$ & 61 & 57 & 53 & 48 \\
$\mathrm{Na}(\mathrm{ppm})$ & 137 & 211 & 284 & 358 \\
$\mathrm{Cl}(\mathrm{ppm})$ & 230 & 316 & 403 & 489 \\
$\mathrm{~S}(\mathrm{ppm})$ & 181 & 212 & 242 & 272 \\
$\mathrm{Fe}(\mathrm{ppm})$ & 1.69 & 1.27 & 0.85 & 0.42 \\
$\mathrm{Zn}(\mathrm{ppm})$ & 0.22 & 0.17 & 0.11 & 0.06 \\
$\mathrm{Mn}(\mathrm{ppm})$ & 0.27 & 0.2 & 0.14 & 0.07 \\
$\mathrm{Cu}(\mathrm{ppm})$ & 0.02 & 0.015 & 0.01 & 0.005 \\
$\mathrm{~B}(\mathrm{ppm})$ & 0.35 & 0.44 & 0.54 & 0.63 \\
\hline
\end{tabular}

The leaves were dried and ground using a laboratory mill (Thomas Scientific, USA) to pass through a $0.5-\mathrm{mm}$ sieve. The leaves were analysed for total nitrogen using Kjeldahl digestion (Nelson and Sommers, 1982). The remaining ground leaves were subjected to dry ash digestion at $550{ }^{\circ} \mathrm{C}$ for $2 \mathrm{~h}$. The cooled ash was moisturized in 3-4 drops of diluted $\mathrm{HNO}_{3}(1: 1)$ on a heating plate until $\mathrm{HNO}_{3}$ completely evaporated. The aliquot was used to determine concentration of $\mathrm{P}$ by ammonium molybdate-vandate method (Chapman and Pratt, 1961) using a spectrophotometer (Genesys 10, USA). Analysis of $\mathrm{K}, \mathrm{Ca}, \mathrm{Mg}, \mathrm{Na}$, $\mathrm{Cl}, \mathrm{Fe}, \mathrm{Zn}, \mathrm{Mn}, \mathrm{Cu}$ and $\mathrm{B}$ was performed as described by the Association of Official Analytical Chemists (Horwitz, 2000). The remaining ash was dissolved in diluted $\mathrm{HCl}$ (1:1) and put in lanthanum and lithium solutions. The aliquots were analysed for $\mathrm{K}$ and $\mathrm{Na}$ using a flame photometer (Sherwood Scientific Ltd 410, UK) and $\mathrm{Ca}, \mathrm{Mg}$, $\mathrm{Fe}, \mathrm{Zn}, \mathrm{Mn}, \mathrm{Cu}$ and $\mathrm{B}$ by atomic absorption spectroscopy (Varian model, Agilent Technologies Co., USA). Chloride was determined by titration using $\quad 0.05 \mathrm{~N} \quad \mathrm{AgNO}_{3}$ (Richards, 1954.). Concentrations of $\mathrm{Cd}, \mathrm{Cr}, \mathrm{Ni}$ and $\mathrm{Pb}$ were determined using microwave digestion system (Microwave Digestion Lab Station MD 01,
Milestone S.r.L., Italy) and Solar 969 Atomic Absorption spectroscopy (TJA Solution co., UK) (Rechcigl and Payne, 1990).

Net daily water consumption was calculated according to the following equations:

First equation: $\mathrm{A}=\mathrm{B}-\mathrm{D}$

Where $A$ is the net water consumption $\left(\mathrm{m}^{3}\right), B$ is the quantity of applied water $\left(\mathrm{m}^{3}\right)$, and $\mathrm{D}$ is the quantity of drain water $\left(\mathrm{m}^{3}\right)$.

Second equation: $\mathrm{Y}=\mathrm{A} \times \mathrm{P} \times \mathrm{C}$

Where $\mathrm{Y}$ is the quantity of the nutrient taken by plant from treated wastewater $(\mathrm{g}), \mathrm{A}$ is the net water consumption $\left(\mathrm{m}^{3}\right), \mathrm{P}$ is the percentage of wastewater in nutrient solution, and $\mathrm{C}$ is the concentration of a certain nutrient $(\mathrm{N}, \mathrm{P}$, and/or $\mathrm{K})$ $\left(\mathrm{g} \mathrm{m}^{-3}\right)$.

Third equation: $\mathrm{WUE}=\mathrm{BY} / \mathrm{A}$

Where WUE is water use efficiency $\left(\mathrm{kg} \mathrm{m}^{-3}\right), \mathrm{BY}$ is the biological yield (shoots and flowers) $(\mathrm{kg})$, and $A$ is the net water consumption $\left(\mathrm{m}^{-3}\right)$. In all calculations, the volume of discharged solutions after being replaced with fresh ones was not considered. 
In addition, biomass water use efficiency (WUE) was calculated for shoot fresh mass and flower mass (bud number $\mathrm{x}$ bud mass) for each treatment as follows: average shoot fresh mass or flower mass per plant at harvest / total volume of irrigation solution supplied per plant from the first day of treatment application until harvest.

\subsection{Statistical analysis}

Data were subjected to analysis of variance by the General Linear Models procedure using SAS (Statistical Analysis System, version 9.1, 2002). Mean comparison was performed using the Least Significant Difference (LSD) method at $P \leq 0.05$.

\section{RESULTS AND DISCUSSION}

\subsection{Plant growth and flowering}

Stem diameter, leaf number, root length or bud number was not affected by the irrigation solution (Table 2). With the exception of root mass, all other parameters were significantly greater in plants irrigated with $\mathrm{N}$ or $3 \mathrm{~N}: 1 \mathrm{~W}$ solution than in plants irrigated with $1 \mathrm{~N}: 1 \mathrm{~W}$ or $1 \mathrm{~N}: 3 \mathrm{~W}$ solution (Table 2, Fig. 1). Plants irrigated with $1 \mathrm{~N}: 3 \mathrm{~W}$ solution had the least root fresh and dry mass.

Table 2: Growth and flowering of Asiatic lily 'Brunello' as influenced by irrigation with different ratios of a nutrient solution $(\mathrm{N})$ to treated wastewater $(\mathrm{W})$ in a closed soilless culture

\begin{tabular}{l|llll}
\hline \multirow{2}{*}{ Variables } & \multicolumn{4}{|c}{ Irrigation solution treatments $^{\mathrm{Z}}$} \\
\cline { 2 - 5 } & $\mathrm{N}$ & $3 \mathrm{~N}: 1 \mathrm{~W}$ & $1 \mathrm{~N}: 1 \mathrm{~W}$ & $1 \mathrm{~N}: 3 \mathrm{~W}$ \\
\hline Stem length $(\mathrm{cm})$ & $34.4 \mathrm{ab}$ & $36.2 \mathrm{a}$ & $32.7 \mathrm{~b}$ & $32.9 \mathrm{~b}$ \\
Stem diameter $(\mathrm{mm})$ & $9.88 \mathrm{NS}$ & $9.13 \mathrm{NS}$ & $9.5 \mathrm{NS}$ & $9.48 \mathrm{NS}$ \\
Leaf number & $109 \mathrm{NS}$ & $107 \mathrm{NS}$ & $109 \mathrm{NS}$ & $109 \mathrm{NS}$ \\
Shoot fresh mass $(\mathrm{g})$ & $30.1 \mathrm{a}$ & $32.4 \mathrm{a}$ & $27.0 \mathrm{~b}$ & $26.5 \mathrm{~b}$ \\
Shoot dry mass $(\mathrm{g})$ & $3.4 \mathrm{ab}$ & $3.82 \mathrm{a}$ & $3.14 \mathrm{~b}$ & $3.05 \mathrm{~b}$ \\
Root length $(\mathrm{cm})$ & 12.53 & 12.19 & 12.34 & 12.29 \\
Root fresh mass $(\mathrm{g})$ & $3.4 \mathrm{a}$ & $3.6 \mathrm{a}$ & $3.2 \mathrm{a}$ & $2.8 \mathrm{~b}$ \\
Root dry mass $(\mathrm{g})$ & $0.208 \mathrm{~b}$ & $0.251 \mathrm{a}$ & $0.237 \mathrm{ab}$ & $0.150 \mathrm{c}$ \\
Peduncle length $(\mathrm{cm})$ & $4.25 \mathrm{ab}$ & $4.82 \mathrm{a}$ & $3.52 \mathrm{c}$ & $3.85 \mathrm{bc}$ \\
Bud number & $3.4 \mathrm{NS}$ & $3.5 \mathrm{NS}$ & $3.3 \mathrm{NS}$ & $3.3 \mathrm{NS}$ \\
Bud length (cm) & $4.27 \mathrm{ab}$ & $4.42 \mathrm{a}$ & $3.48 \mathrm{c}$ & $3.68 \mathrm{bc}$ \\
Bud mass (g) & $14.95 \mathrm{a}$ & $17.62 \mathrm{a}$ & $10.93 \mathrm{~b}$ & $11.83 \mathrm{~b}$ \\
\hline
\end{tabular}

${ }^{\mathrm{z}}$ Means within rows having different letters are significantly different according to LSD $(P \leq 0.05)$. Values are average of 10 plants. NS means non-significant within rows. 


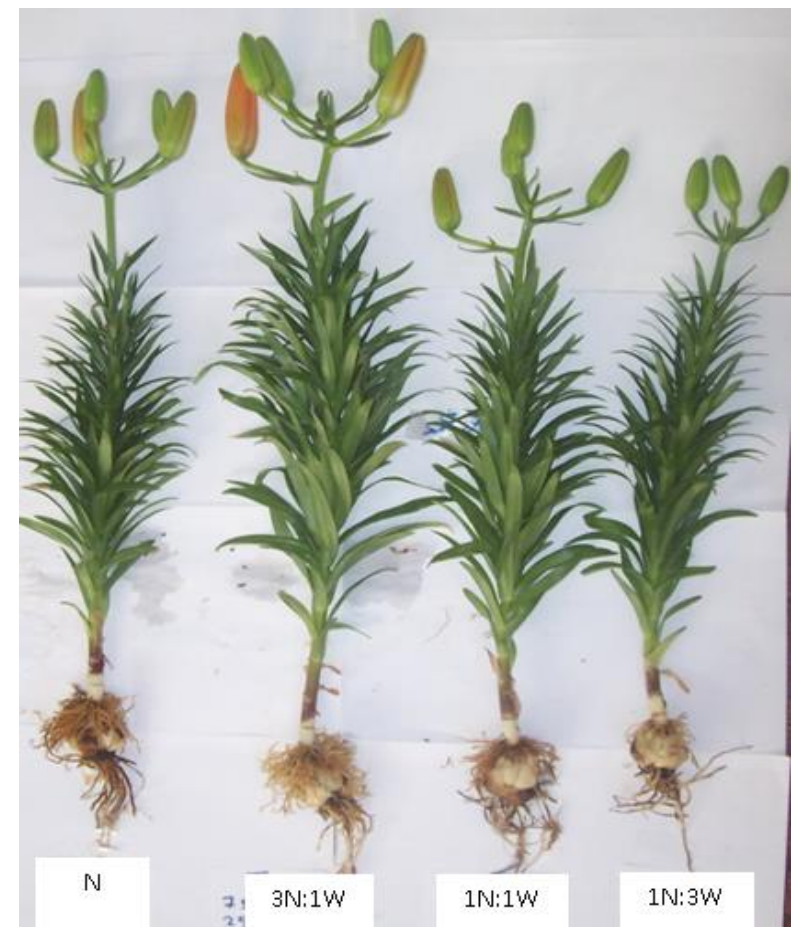

Figure 1: Growth of Asiatic lily 'Brunello' as influenced by irrigation with different ratios of a nutrient solution (N) and treated wastewater $(\mathrm{W})$.

\subsection{Plant tissue analysis}

Leaf analysis revealed that concentrations of only $\mathrm{K}, \mathrm{Na}, \mathrm{Fe}$ and $\mathrm{B}$ were affected by the irrigation solution (Table 3). Plants receiving N, 3N:1W or $1 \mathrm{~N}: 3 \mathrm{~W}$ solution had the highest concentrations of $\mathrm{K}\left(3.28,3.23\right.$ or $3.06 \mathrm{~g} \mathrm{~kg}^{-1}$ dry mass, respectively) and $\mathrm{B}\left(75.4,64.4\right.$ or $53.5 \mathrm{mg} \mathrm{kg}{ }^{-1}$ dry mass, respectively). Furthermore, the highest level of $\mathrm{Na}$ $\left(0.90,0.94\right.$ or $0.99 \mathrm{~g} \mathrm{~kg}^{-1}$ dry mass) was detected in plants irrigated with $3 \mathrm{~N}: 1 \mathrm{~W}, 1 \mathrm{~N}: 1 \mathrm{~W}$ or $1 \mathrm{~N}: 3 \mathrm{~W}$, respectively. Plants irrigated with $3 \mathrm{~N}: 1 \mathrm{~W}$ or $1 \mathrm{~N}: 3 \mathrm{~W}$ had the highest level of $\mathrm{Fe}(862$ or $694 \mathrm{mg} \mathrm{kg}^{-1}$ dry mass). There was no significant effect of the irrigation solution on tissue content of the heavy metal $\mathrm{Cd}, \mathrm{Cr}, \mathrm{Ni}$ or $\mathrm{Pb}$ (Table 3). 
Table 3: Concentrations of elements in the leaves of Asiatic lily 'Brunello' as influenced by irrigation with different ratios of a nutrient solution $(\mathrm{N})$ to treated wastewater $(\mathrm{W})$ in a closed soilless culture.

\begin{tabular}{|c|c|c|c|c|c|}
\hline \multirow{2}{*}{ Variables } & \multirow{2}{*}{ Units } & \multicolumn{4}{|c|}{ Irrigation solution treatments ${ }^{\mathrm{z}}$} \\
\hline & & $\mathrm{N}$ & $3 \mathrm{~N}: 1 \mathrm{~W}$ & $1 \mathrm{~N}: 1 \mathrm{~W}$ & $1 \mathrm{~N}: 3 \mathrm{~W}$ \\
\hline $\mathrm{N}$ & & 2.64 & 2.53 & 2.62 & 2.71 \\
\hline $\mathrm{P}$ & & $0.36 \mathrm{NS}$ & $0.32 \mathrm{NS}$ & $0.29 \mathrm{NS}$ & $0.25 \mathrm{NS}$ \\
\hline K & & $3.28 \mathrm{a}$ & $3.23 \mathrm{a}$ & $2.87 \mathrm{~b}$ & $3.06 \mathrm{ab}$ \\
\hline $\mathrm{Ca}$ & ( $\mathrm{g} \mathrm{kg}^{-1}$ dry mass) & $0.89 \mathrm{NS}$ & $1.23 \mathrm{NS}$ & $0.98 \mathrm{NS}$ & $0.98 \mathrm{NS}$ \\
\hline $\mathrm{Mg}$ & & $0.35 \mathrm{NS}$ & $0.39 \mathrm{NS}$ & $0.35 \mathrm{NS}$ & $0.38 \mathrm{NS}$ \\
\hline $\mathrm{Na}$ & & $0.78 \mathrm{~b}$ & $0.90 \mathrm{ab}$ & $0.94 \mathrm{a}$ & $0.99 \mathrm{a}$ \\
\hline $\mathrm{Cl}$ & & $0.58 \mathrm{NS}$ & $0.7 \mathrm{NS}$ & $0.55 \mathrm{NS}$ & $0.58 \mathrm{NS}$ \\
\hline $\mathrm{Fe}$ & & $564 \mathrm{~b}$ & $862 \mathrm{a}$ & $542 \mathrm{~b}$ & $694 \mathrm{ab}$ \\
\hline $\mathrm{Zn}$ & & $56.2 \mathrm{NS}$ & $50.1 \mathrm{NS}$ & $54.3 \mathrm{NS}$ & $57.8 \mathrm{NS}$ \\
\hline $\mathrm{Mn}$ & & $28.6 \mathrm{NS}$ & $28.3 \mathrm{NS}$ & $25.3 \mathrm{NS}$ & $29.1 \mathrm{NS}$ \\
\hline $\mathrm{Cu}$ & & $9.97 \mathrm{NS}$ & $8.36 \mathrm{NS}$ & $8.15 \mathrm{NS}$ & $8.72 \mathrm{NS}$ \\
\hline B & (mg kg ${ }^{-1}$ dry mass) & $75.4 \mathrm{a}$ & $64.4 \mathrm{a}$ & $31.7 \mathrm{~b}$ & $53.5 \mathrm{ab}$ \\
\hline $\mathrm{Cd}$ & & $0.02 \mathrm{NS}$ & $0 \mathrm{NS}$ & $0 \mathrm{NS}$ & $0 \mathrm{NS}$ \\
\hline $\mathrm{Cr}$ & & $0.3 \mathrm{NS}$ & $0.35 \mathrm{NS}$ & $0.46 \mathrm{NS}$ & $0.35 \mathrm{NS}$ \\
\hline $\mathrm{Ni}$ & & $0.65 \mathrm{NS}$ & $0.73 \mathrm{NS}$ & $0.7 \mathrm{NS}$ & $0.68 \mathrm{NS}$ \\
\hline $\mathrm{Pb}$ & & $0.007 \mathrm{NS}$ & $0.007 \mathrm{NS}$ & $0.003 \mathrm{NS}$ & $0.002 \mathrm{NS}$ \\
\hline
\end{tabular}

${ }^{\mathrm{z}}$ Means within rows having different letters are significantly different according to LSD $(P \leq 0.05)$. NS means nonsignificant within rows.

\subsection{Electrical conductivity and $\mathrm{pH}$ of the supply and drain solutions}

Two cycles of recirculation of the irrigation solutions were performed throughout the experiment (Fig. 2-5). At the start of the first cycle, the solutions $\mathrm{N}, 3 \mathrm{~N}: 1 \mathrm{~W}, 1 \mathrm{~N}: 1 \mathrm{~W}$ and $1 \mathrm{~N}: 3 \mathrm{~W}$ had EC of $1.65,1.73,1.91$ and $2.12 \mathrm{dS} \mathrm{m}^{-1}$ and $\mathrm{pH}$ of 6.58, 7.72, 7.92 and 8.01, respectively (Table 1). At the start of circulation, the drain solutions from beds receiving $\mathrm{N}, 3 \mathrm{~N}: 1 \mathrm{~W}, 1 \mathrm{~N}: 1 \mathrm{~W}$ or $1 \mathrm{~N}: 3 \mathrm{~W}$ had EC of $1.62,1.68,1.87$ or $2.09 \mathrm{dS} \mathrm{m}^{-1}$ and $\mathrm{pH}$ of $6.65,7.79,7.98$ or 8.07 , respectively. The threshold EC ( $\left.2.3 \mathrm{dS} \mathrm{m}^{-1}\right)$ of the drain solutions for the treatments $\mathrm{N}, 3 \mathrm{~N}: 1 \mathrm{~W}, 1 \mathrm{~N}: 1 \mathrm{~W}$ and $1 \mathrm{~N}: 3 \mathrm{~W}$ was attained after 18, 17, 15 and 12 days of circulation, respectively. In the second cycle, the threshold EC was attained (after 13 days) only when $1 \mathrm{~N}: 3 \mathrm{~W}$ was used because the experiment was terminated, thus was not long enough to reach the target EC when the other irrigation solutions were used. Throughout the experiment, the average EC of the supply solution was 1.76, 1.81, 1.96 and $2.09 \mathrm{dS} \mathrm{m}^{-1}$ (Fig. 2) and of the drain solution was $1.77,1.82,1.97$ and $2.11 \mathrm{dS} \mathrm{m}^{-1}$ for the treatments $\mathrm{N}, 3 \mathrm{~N}: 1 \mathrm{~W}, 1 \mathrm{~N}: 1 \mathrm{~W}$ and $1 \mathrm{~N}: 3 \mathrm{~W}$, respectively (Fig. 3).

In both cycles, EC of all supply (circulating) and drain solutions decreased in the first few days of circulation, then increased and the solution $1 \mathrm{~N}: 3 \mathrm{~W}$ and its drain had the highest EC followed by $1 \mathrm{~N}$ :1W (Fig. 2 and 3). Moreover, EC values of the supply solution $3 \mathrm{~N}: 1 \mathrm{~W}$ or its drain were not different from those of the solution $\mathrm{N}$ or its drain in the first cycle, but were higher in the second cycle. $\mathrm{pH}$ of supply (Fig. 4) and drain (Fig. 5) solutions increased in both cycles. At the end of the experiment, $\mathrm{pH}$ of the supply solutions $\mathrm{N}, 3 \mathrm{~N}: 1 \mathrm{~W}$, $1 \mathrm{~N}: 1 \mathrm{~W}$ and $1 \mathrm{~N}: 3 \mathrm{~W}$ was $7.22,8.44,8.52$ and 8.97 and of the drain solutions was 7.29, 8.49, 8.57 and 9.05 , respectively. In both cycles, the supply solution $\mathrm{N}$ and its drain had the lowest $\mathrm{pH}$. 


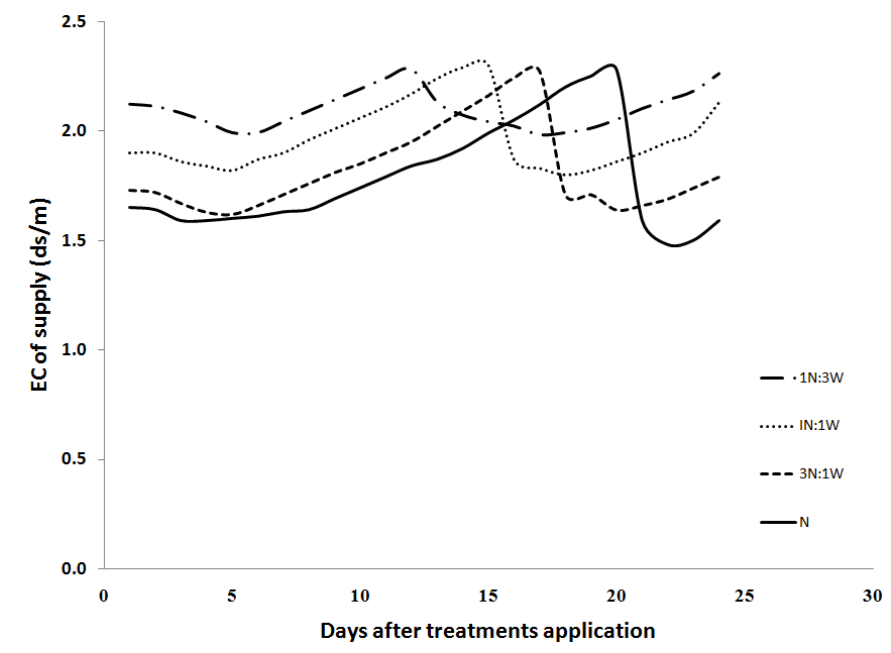

Figure 2: Changes in EC of the supply solution with time of circulation as influenced by irrigation Asiatic lily 'Brunello' with different ratios of a nutrient solution $(\mathrm{N})$ and treated wastewater $(\mathrm{W})$.

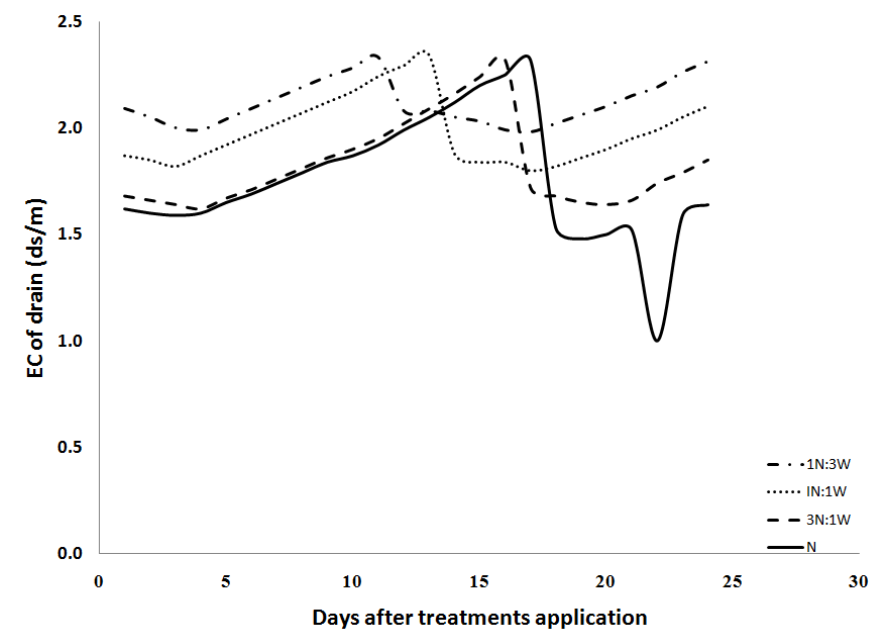

Figure 3 and Figure 2: Changes in EC of the drain solution with time of circulation as influenced by irrigation Asiatic lily 'Brunello' with different ratios of a nutrient solution $(\mathrm{N})$ and treated wastewater $(\mathrm{W})$.

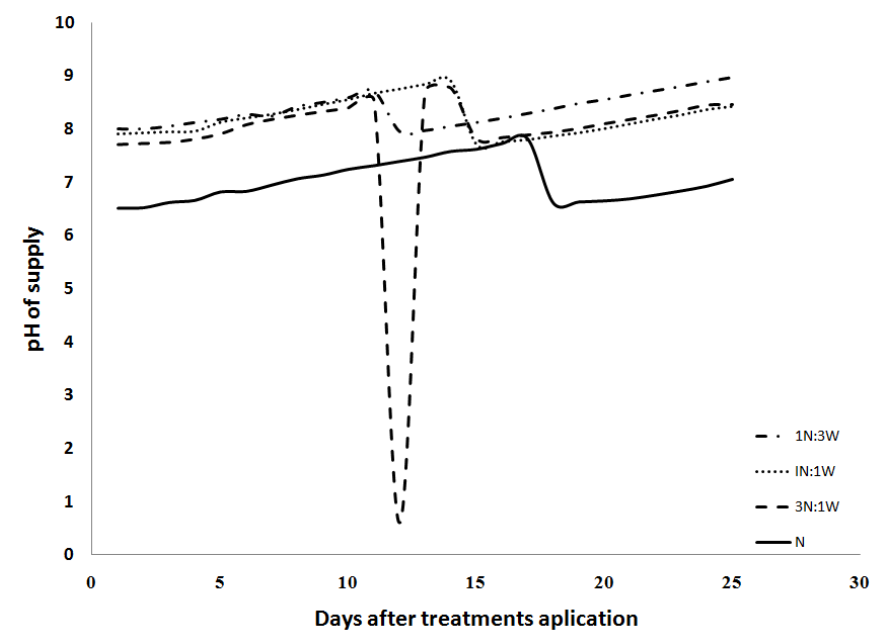

Figure 4: Changes in $\mathrm{pH}$ of the supply solution with time of circulation as influenced by irrigation Asiatic lily 'Brunello' with different ratios of a nutrient solution $(\mathrm{N})$ and treated wastewater $(\mathrm{W})$. 


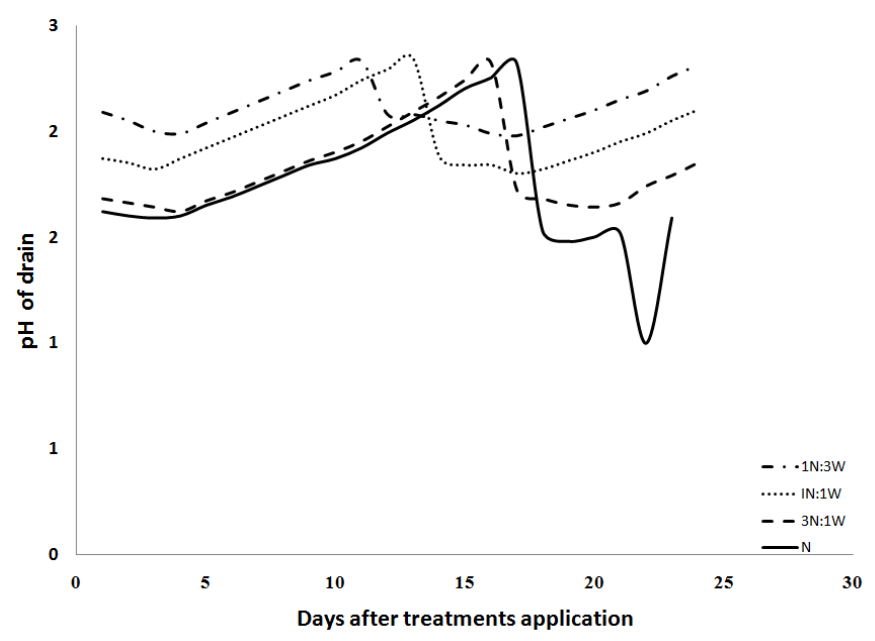

Figure 5: Changes in $\mathrm{pH}$ of the drain solution with time of circulation as influenced by irrigation Asiatic lily 'Brunello' with different ratios of a nutrient solution (N) and treated wastewater (W).

\subsection{Savings in irrigation solutions and biomass water use efficiency}

Savings in the nutrient solution $\mathrm{N}$ were $10.11 \mathrm{~m}^{-2}$ day $^{-1}$ and in the nutrients $\mathrm{N}, \mathrm{P}$ and $\mathrm{K}$ were 1850 , 347 and $1870 \mathrm{mg} \mathrm{m}^{-2}$ day $^{-1}$ respectively. The highest savings were recorded when $1 \mathrm{~N}: 3 \mathrm{~W}$ solution was used (Table 4). It was observed that biomass WUE was $1.16,1.25,1.04$ or $1.06 \mathrm{~kg} \mathrm{~m}^{-3}$ for shoot fresh mass and 2.0, 2.37, 1.39 or $1.56 \mathrm{~kg} \mathrm{~m}^{-3}$ for flower mass, when $\mathrm{N}, 3 \mathrm{~N}: 1 \mathrm{~W}$, $1 \mathrm{~N}: 1 \mathrm{~W}$ or $1 \mathrm{~N}: 3 \mathrm{~W}$ solutions were used, respectively.

Table 4: Effect of irrigation of Asiatic lily 'Brunello' with different ratios of a nutrient solution (N) to treated wastewater (W) on average savings in the irrigation solutions and the nutrients $\mathrm{N}, \mathrm{P}$ and $\mathrm{K}$ due to the use of (W)

\begin{tabular}{|c|c|c|c|c|}
\hline \multirow{2}{*}{ Variables } & \multicolumn{3}{|c|}{ Irrigation solution treatments $^{\mathrm{z}}$} & \multirow[b]{2}{*}{$1 \mathrm{~N}: 3 \mathrm{~W}$} \\
\hline & $\mathrm{N}$ & $3 \mathrm{~N}: 1 \mathrm{~W}$ & $1 \mathrm{~N}: 1 \mathrm{~W}$ & \\
\hline Supplied irrigation solution $\left(1 \mathrm{~m}^{-2} \mathrm{day}^{-1}\right)$ & $26.7 \mathrm{NS}$ & $26.7 \mathrm{NS}$ & $26.7 \mathrm{NS}$ & $26.7 \mathrm{NS}$ \\
\hline Drainage $\left(1 \mathrm{~m}^{-2} \mathrm{day}^{-1}\right)$ & 12.9 & 13.2 & 13.2 & 13.3 \\
\hline Consumed irrigation solution ${ }^{\mathrm{u}}\left(1 \mathrm{~m}^{-2}\right.$ day $\left.^{-1}\right)$ & $13.7 \mathrm{NS}$ & $13.5 \mathrm{NS}$ & $13.4 \mathrm{NS}$ & $13.4 \mathrm{NS}$ \\
\hline Consumed $\mathrm{N}$ solution ${ }^{\mathrm{w}}\left(1 \mathrm{~m}^{-2} \mathrm{day}^{-1}\right)$ & $13.7 \mathrm{a}$ & $10.1 \mathrm{~b}$ & $6.7 \mathrm{c}$ & $3.3 \mathrm{~d}$ \\
\hline Saved $(\mathrm{N})$ solution ${ }^{\mathrm{x}}\left(\mathrm{l} \mathrm{m}^{-2}\right.$ day $\left.^{-1}\right)$ & $0 \mathrm{~d}$ & $3.4 \mathrm{c}$ & $6.7 \mathrm{~b}$ & $10.1 \mathrm{a}$ \\
\hline Saved $\mathrm{N}^{\mathrm{y}}\left(\mathrm{mg} \mathrm{m}^{-2}\right.$ day $\left.^{-1}\right)$ & $0 \mathrm{~d}$ & $621 \mathrm{c}$ & $1236 \mathrm{~b}$ & $1850 \mathrm{a}$ \\
\hline Saved $\mathrm{P}^{\mathrm{y}}\left(\mathrm{mg} \mathrm{m}^{-2}\right.$ day $\left.^{-1}\right)$ & $0 \mathrm{~d}$ & $116 \mathrm{c}$ & $232 \mathrm{~b}$ & $347 \mathrm{a}$ \\
\hline Saved $\mathrm{K}^{\mathrm{y}}\left(\mathrm{mg} \mathrm{m}^{-2}\right.$ day $\left.^{-1}\right)$ & $0 \mathrm{~d}$ & $628 \mathrm{c}$ & $1249 \mathrm{~b}$ & $1870 \mathrm{a}$ \\
\hline
\end{tabular}

"Volume of supplied irrigation solution - volume of drainage.

${ }^{\mathrm{w}}$ Volume of consumed irrigation solution *\% (N) solution in irrigation solution.

${ }^{\mathrm{x}}$ Volume of consumed irrigation solution $* \%(\mathrm{~W})$ in irrigation solution.

${ }^{\mathrm{y}}$ Amount of nutrient consumed using $(\mathrm{N})$ solution - amount of nutrient consumed using the considered irrigation solution, which $=$ consumed irrigation solution $*$ proportion of $(\mathrm{N})$ solution in the considered irrigation solution * concentration of the nutrient in $(\mathrm{N})$ solution.

${ }^{\mathrm{z}}$ Means within rows having different letters are significantly different according to $\operatorname{LSD}(P \leq 0.05)$.

NS means non-significant within rows. 
Treated wastewater had potential as irrigation water for production of Asiatic lily, when mixed with potable water. However, high percentage of treated wastewater was a limiting factor. Mixing a nutrient solution, usually recommended for Asiatic lily, with treated wastewater at a ratio of $1: 1$ or $1: 3$ did not prove to be feasible since the plants exhibited growth retardation (Table 2). This may be attributed to exposure of the plants to salinity stress because of the high EC of the circulating solution (Fig. 2) and the drain solution (Fig. 3) around the roots. This is in agreement with studies which indicated that continual reuse of the drain solution in closed soilless culture usually increases EC of the circulating solution (Baas and Van den Berg, 1999; Bar-Yosef et al., 2001; Daood and Karam, 2007; Karam and Al-Daood, 2005). This effect was evident in the current study when the nutrient solution $\mathrm{N}$ was used alone for irrigation (Fig. 2). However, the problem of elevated EC was aggravated when $1 \mathrm{~N}: 1 \mathrm{~W}$ or $1 \mathrm{~N}: 3 \mathrm{~W}$ was used. This may be explained by the high concentrations of $\mathrm{Na}, \mathrm{Cl}$ and $\mathrm{HCO}_{3}$ in treated wastewater which rendered the initial EC of $1 \mathrm{~N}: 1 \mathrm{~W}$ and $1 \mathrm{~N}: 3 \mathrm{~W}$ high (1.91 and $2.12 \mathrm{dS} \mathrm{m}^{-1}$, respectively) (Table 1) and may have resulted in accumulation of $\mathrm{Na}$ and $\mathrm{Cl}$ in the root zone (Karam et al., 2006; Karam et al., 2009). Plant growth is adversely affected under salt stress due to osmotically induced water stress, specific ion toxicity due to high concentration of $\mathrm{Na}^{+}$and $\mathrm{Cl}^{-}$, nutrient ion imbalance due to high levels of $\mathrm{Na}^{+}$and $\mathrm{Cl}^{-}$which reduce uptake of $\mathrm{K}^{+}$, $\mathrm{NO}_{3}{ }^{-}$and $\mathrm{PO}_{4}{ }^{3-}$ (Greenway and Munns, 1980).

Accumulation of $\mathrm{Na}$ in the circulating solution in closed soilless culture may lead to reduced level of $\mathrm{K}$ in the circulating solution (Karam and AlDaood, 2005; Savvas and Manos, 1999; Sonneveld, 1981) and the plant (Savvas et al., 2009). Accumulation of $\mathrm{Na}$ is expected to be more significant when zeolite is used as a substrate due to adsorption of $\mathrm{K}$ ions by zeolite after replacing $\mathrm{Na}$ ions resulting in less availability of $\mathrm{K}$ and higher concentration of $\mathrm{Na}$ in the substrate (Williams and Nelson, 1997). The problem of $\mathrm{Na}$ accumulation is aggravated when saline water is used in closed cultures (Pardossi et al., 2006). Reduced $\mathrm{K}$ uptake by the plant is attributed to the competition between $\mathrm{K}$ and $\mathrm{Na}$ for the absorption sites of the roots (Rusan et al., 2003). In the current study, the suppressive effect of $\mathrm{Na}$ on $\mathrm{K}$ uptake was evident from the lower $\mathrm{K}$ and higher $\mathrm{Na}$ contents in plants irrigated with $1 \mathrm{~N}: 1 \mathrm{~W}$ or $1 \mathrm{~N}: 3 \mathrm{~W}$ compared to those irrigated with $\mathrm{N}$ or $3 \mathrm{~N}: 1 \mathrm{~W}$ (Table 3). In fact, $\mathrm{K}$ concentration in plants irrigated with the former solutions was less than the sufficiency range reported for Easter lily (3.3$5.0 \%$ ) (Jones et al., 1991). It is obvious that the competition was advantageous to $\mathrm{Na}$ when $1 \mathrm{~N}: 1 \mathrm{~W}$ or $1 \mathrm{~N}: 3 \mathrm{~W}$ solution was used due to the high initial $\mathrm{Na}$ and low initial $\mathrm{K}$ contents in those solutions (Table 1).

In addition to the negative effect of $\mathrm{Na}$ on $\mathrm{K}$ acquisition by the roots, high levels of $\mathrm{Na}$ under saline-sodic conditions may disrupt the integrity of root membranes and alter their selectivity from $\mathrm{K}$ to $\mathrm{Na}$ (Grattan and Grieve, 1999). According to the authors, the selectivity of the root system for $\mathrm{K}$ over Na must be sufficient to meet the levels of $\mathrm{K}$ required for metabolic processes, ion transport regulation and osmotic adjustment which affect water uptake. Fulfilling the need of plants for K may be achieved by increasing concentration of $\mathrm{K}$ in the irrigation solution. In the present study, the high initial content of $\mathrm{K}$ in the irrigation solutions (N) and 3N:1W (Table 1) was apparently sufficient to increase selectivity of the roots for $\mathrm{K}$ over $\mathrm{Na}$, resulting in increased $\mathrm{K}$ and reduced $\mathrm{Na}$ contents in plants irrigated with those solutions (Table 3).

Only the plants that were irrigated with $1 \mathrm{~N}: 3 \mathrm{~W}$ exhibited reduced root fresh mass, implying reduced water content, probably due to elevated EC $\left(2.31 \mathrm{dS} \mathrm{m}^{-1}\right)$ of the drain solution at the end of the experiment (Fig. 3). Those plants also exhibited reduced root dry mass implying reduced root mass, which occurs under salinity conditions (Shannon and Grieve, 1999), thus reduced water uptake. Results of the present study confirm findings of Karam and Al-Daood (2005) who reported reduction in root fresh mass of Asiatic lily 'Zsa Zsa' only when EC of the drain solution reached $2.2 \mathrm{dS} \mathrm{m}^{-1}$ and in root dry mass as EC increased up to $2.0 \mathrm{dS} \mathrm{m} \mathrm{m}^{-1}$. Reduced water uptake by the plant may reduce $\mathrm{Ca}$ transport in the plant since the rate of transpiration is regarded as the main force for Ca transport to the leaves (Clarkson, 1984). However, retardation in growth of plants irrigated with $1 \mathrm{~N}: 1 \mathrm{~W}$ or $1 \mathrm{~N}: 3 \mathrm{~W}$ is not likely to be due limited $\mathrm{Ca}$ uptake since the plants were not significantly different from those irrigated with $\mathrm{N}$ 
or $3 \mathrm{~N}: 1 \mathrm{~W}$ solution with respect to $\mathrm{Ca}$ content in the leaves (Table 3).

Electrical conductivity of the supply and drain solutions for all treatments decreased in the first 6 days of circulation (Fig. 2 and 3), which may be attributed to the high ion adsorption and cation exchange capacity of zeolitic tuff (Mumpton, 1983). The $\mathrm{pH}$ of all supply and drain solutions increased with increasing EC (Fig. 4 and 5), which confirms findings of Karam and Al-Daood (2005). Increased $\mathrm{pH}$ in the root zone usually limits absorption of micronutrients. In the present study, $\mathrm{pH}$ of the drain solution increased above 8 for all treatments except for the solution $(\mathrm{N})$, yet there was no effect of $\mathrm{pH}$ or $\mathrm{EC}$ on tissue contents of micronutrients other than $\mathrm{Fe}$ and $\mathrm{B}$ (Table 3), which may be due to the relatively short duration of circulation in each cycle. Our findings are in agreement with those reported for Asiatic lily 'Zsa Zsa' which revealed no effect of EC on tissue content of micronutrients except Mo (Karam and Al-Daood, 2005).

Tissue contents of only $\mathrm{K}, \mathrm{Na}, \mathrm{Fe}$ and $\mathrm{B}$ were significantly affected by the irrigation solution (Table 3). Similarity in tissue $\mathrm{N}$ content at all EC values implies lack of effect of $\mathrm{EC}$ on $\mathrm{N}$ uptake as was reported for Asiatic lily 'Zsa Zsa' (Karam and Al-Daood, 2005) with EC of $2.2 \mathrm{dS} \mathrm{m}^{-1}$ and petunia (Petunia $\times$ hybrid (Hook) Vilm.) and begonia (Begonia 'Semperflorens Cultorum Group') (James and van Iersel, 2001) even with EC of $3 \mathrm{dS} \mathrm{m} \mathrm{m}^{-1}$. Tissue content of $\mathrm{Fe}$ for all treatments (Table 3) was substantially higher than the upper level of sufficiency range for Easter lily (60-200 ppm) (Jones et al., 1991), suggesting luxury consumption. Tissue contents of $\mathrm{P}, \mathrm{Ca}, \mathrm{Mg}$, $\mathrm{Zn}, \mathrm{Cu}$ and $\mathrm{B}$ for all treatments were within the sufficiency range for Easter lily $(0.25-0.7 \%$, 0.6$1.5 \%, 0.2-0.7 \%, 20-200 \mathrm{ppm}, 8-50 \mathrm{ppm}$ and $25-$ $75 \mathrm{ppm}$, respectively), whereas contents of $\mathrm{N}$ and $\mathrm{Mn}$ were lower than the sufficiency range (3.3$4.8 \% \mathrm{~N}$ and 35-200 ppm Mn) (Jones et al., 1991).

Only plants irrigated with $3 \mathrm{~N}: 1 \mathrm{~W}$ were comparable to those irrigated with $(\mathrm{N})$ solution (Table 2). This may be explained by the similar EC conditions that the plants were exposed to for most part of the experiment (Fig. 2 and 3). Although the first cycle of circulation lasted for 18-19 days, the difference in EC between the two solutions or their drains was slight. In the second cycle, the difference in EC between the two solutions was large, but the cycle lasted for only 7-8 days. The threshold EC $\left(2.3 \mathrm{dS} \mathrm{m}^{-1}\right)$ of the drain solution of the treatments $\mathrm{N}, 3 \mathrm{~N}: 1 \mathrm{~W}, 1 \mathrm{~N}: 1 \mathrm{~W}$ and $1 \mathrm{~N}: 3 \mathrm{~W}$ was attained after $18,17,15$ and 12 days of circulation, respectively (Fig. 3). Accordingly, using the solution $1 \mathrm{~N}: 3 \mathrm{~W}$ the replacement with a fresh solution every 12 days was necessary, whereas using $\mathrm{N}$ or $3 \mathrm{~N}: 1 \mathrm{~W}$ solution required replacement with new solutions after 1718 days. Karam and Al-Daood (2005) were able to achieve a target EC of $2.2 \mathrm{dS} \mathrm{m}^{-1}$ after 20 days of circulation of a nutrient solution in a closed soilless culture of Asiatic lily 'Zsa Zsa'.

Stem diameter, leaf number, root length or bud number was not affected by the treatment (Table 2), indicating that EC up to $2.3 \mathrm{dS} \mathrm{m}^{-1}$ did not affect those parameters. This confirms results obtained by Karam and Al-Daood (2005) which revealed no change in leaf number in Asiatic lily 'Zsa Zsa' at EC 1.6-2.2 $\mathrm{dS} \mathrm{m}^{-1}$ or in stem diameter or bud number at EC 1.8-2.2 $\mathrm{dS} \mathrm{m}^{-1}$. In the current study, the plants irrigated with $1 \mathrm{~N}: 1 \mathrm{~W}$ or $1 \mathrm{~N}: 3 \mathrm{~W}$ were exposed to EC above $1.8 \mathrm{dS} \mathrm{m}^{-1}$ throughout the experiment (Fig. 2 and 3) and exhibited reduced stem length, shoot fresh mass and bud mass (Table 2), and those irrigated with $1 \mathrm{~N}: 3 \mathrm{~W}$ exhibited reduced root fresh and dry mass. This implies that 'Brunello' cultivar is quite sensitive to salinity as was reported for other cultivars of Asiatic lily. For example, Karam and Al-Daood (2005) reported reduced stem length and diameter, shoot fresh and dry mass, peduncle length and bud number in 'Zsa Zsa' lily as EC of the drain solution increased from 1.6 to $1.8 \mathrm{dS} \mathrm{m}^{-1}$ and reduced stem length, shoot dry mass and peduncle length as EC increased from 1.8 to $2.0 \mathrm{dS} \mathrm{m}^{-1}$. Daood and Karam (2007) also demonstrated that a rise of $0.48 \mathrm{dS} \mathrm{m}^{-1}$ in EC was accompanied with reductions of $10 \%$ in stem length, $22 \%$ in shoot mass, $32 \%$ in root or bud mass, $13 \%$ in peduncle length and $18 \%$ in bud length in 'Zsa Zsa' lily. Furthermore, Morgan (2006) reported that the ideal EC for lily production in hydroponic cultures is 1.2-1.8 dS m $\mathrm{d}^{-1}$ and that higher EC levels resulted in slow growth, stunted plants and small flowers. Sonneveld et al. (1999) also reported that EC higher than $2.0 \mathrm{dS} \mathrm{m}^{-1}$ caused growth retardation in lily. 
The results of this study can be expanded to other regions where ornamental plants are grown. This can be achieved when using soilless culture in a closed system and where treated wastewater is available. Since wastewater treatment plants exist almost everywhere, and plastic greenhouses are constructed widely in agricultural areas. Also, the soilless culture using zeolite has become very common. All these conditions make this study applicable to different regions and cultures. And good results seem to be achievable.

\section{CONCLUSION}

A nutrient solution mixed with treated wastewater at a ratio of 3:1 may be used to produce Asiatic lily 'Brunello' cut flowers in a closed soilless culture in which the plants are grown in zeolitic tuff and the drain solution is recycled until its EC reaches $2.3 \mathrm{dS} \mathrm{m}^{-1}$. By using such a strategy, it is expected to save daily $3.41 \mathrm{~m}^{-2}$ of the nutrient solution and achieve the highest biomass water use efficiency for shoot fresh mass and flower mass. This translates into savings in fresh water and fertilizers. This research is unique since it investigated for the first time the effect of using mixed treated wastewater on cut flowers. Also, the growing system was closed soilless culture using zeolite. And the most common growing activities in the study area use treated wastewater in open fields to grow forage crops not cut flowers. The advantages of this research can be summarized in using water efficiently in regions where scarcity of water is a major problem such as Jordan. Moreover, nutrients can also be saved while producing high quality cut flowers. Future studies are needed to navigate the efficiency of using similar irrigation management practice in open fields. Furthermore, research can be made to grow different cut flowers and other ornamental plants.

\section{REFERENCES}

Baas, R., van den Berg, D. (1999). Sodium accumulation and nutrient discharge in recirculation systems: a case study with roses. Acta Hortic. 507: 157-164. doi:10.17660/ActaHortic.1999.507.18

Baas, R., Nijssen, H.M.C., van den Berg, T.J.M., Warmenhoven, M.G. (1995). Yield and quality of carnation (Dianthus caryophyllus L.) and gerbera (Gerbera jamesonii L.) in a closed nutrient system as affected by sodium chloride. Sci. Hortic. 61: 273-284. doi:10.1016/0304-4238(94)00728-X

Bar-Yosef, B., Markovich, T., Levkovich, I., Mor, Y. (2001). Gypsophila paniculata response to leachate recycling in a greengreenhouse in Israel. Acta Hortic. 554: 193-203. doi:10.17660/ActaHortic.2001.554.20

Bernstein, N., Asher, T., Haya, F., Pini, S., Ilona, R., Amram, C., Marina, I. (2006). Application of treated wastewater for cultivation of roses (Rosa hybrida) in soil-less culture. Sci. Hortic. 108: 185193. doi:10.1016/j.scienta.2006.02.001

Breck, D.W. (1974). Zeolite Molecular Sieves. John Wiley and Sons, Inc., New York.

Chapman, H.D., Pratt, P.F. (1961). Methods of Analysis for Soils, Plants, and Waters. University of California, Riverside. Div. Agr. Sci. pp. 169-170.
Clarkson, D.T. (1984). Calcium transport between tissues and its distribution in the plant. Plant Cell Environ. 7: 449-456. doi:10.1111/j.13653040.1984.tb01435.x

Damasceno, L.M.O., Andrade Júnior, A.S., Gheyi, H.R., Ribeiro, V.Q., Dias, N.S. (2010). Cultivation of gerbera irrigated with treated domestic effluents. Bras. Eng. Agr. Ambiental 14(6): 582-588. doi:10.1590/S1415-43662010000600003

Daood, B.H., Karam, N.S. (2007). Response of Asiatic lily 'Zsa Zsa' to concentration of urea in a closed soilless culture. Acta Hortic. 747: 263-270. doi:10.17660/ActaHortic.2007.747.31

Grattan, S.R., Grieve, C.M. (1994). Mineral nutrient acquisition and response by plants grown in saline environments, in: Pessarakli, M. (Ed.), Handbook of Plant and Crop Stress. Marcel Dekker, New York, pp. 203-226.

Grattan, S.R., Grieve, C.M. (1999). Salinity-mineral nutrient relations in horticultural crops. Sci. Hortic. 78: 127-157. doi:10.1016/S0304-4238(98)00192-7

Greenway, H., Munns, R. (1980). Mechanisms of salt tolerance in nonhalophytes. Ann. Rev. Plant Physiol. 31: 149-190. doi:10.1146/annurev.pp.31.060180.001053 
Horwitz, W. (2000). Official methods of analysis of AOAC international, $17^{\text {th }}$ ed., vol. 1. AOAC International.

Hussain, I., Raschid, L., Hanjra, M.A., Marikar, F., van der Hoek, W. (2002). Wastewater use in agriculture: review of impacts and methodological issues in valuing impacts. International Water Management Institute (IWMI). IWMI Working Paper 37. Colombo, Sri Lanka, pp. 55.

James, E.C., van Iersel, M.W. (2001). Fertilizer concentration affects growth and flowering of sub irrigated petunias and begonias. HortScience 36(1): 40-44.

Jones Jr., J.B., Wolf, B., Mills, H.A. (1991). Plant Analysis Handbook. Micro-Macro Publishing, Inc., USA.

Karam, N.S., Al-Daood, B.H. (2005). Response of Asiatic lily to nutrient solution recycling in a closed soilless culture. Acta Hortic. 697: 199-212. doi:10.17660/ActaHortic.2005.697.25

Karam, N.S., Mohammad, M.J., Jabr, M.Z. (2009). Fertilization through wastewater of croton (Codiaeum variegatum Blume) in zeolitecontaining substrates. Jordan J. Agr. Sci. 5(4): 407420.

Karam, N.S., Jabr, M.Z., Mohammad, M.J. (2006). Wastewater re-use for croton in substrates amended with zeolitic tuff. J. Plant Nutr. 29: 765-782. doi:10.1080/01904160600567108

Khan, M.A., Shaukat, S.S., Khan, M.A. (2009). Growth, yield and nutrient content of sunflower (Helianthus annuus L.) using treated wastewater from waste stabilization ponds. Pakistan J. Bot. 41(3): 13911399.

Maryam, M. K., Mohammad, A. G. S., Mohammad, V. (2015). Simulation of open-and closed- end border irrigation systems using SYRMOD. Journal Archives of Agronomy and Soil Science 61(7): 929-941. doi:10.1080/03650340.2014.981163.

Mohammad, V. (2012a). Comparison of surface irrigation simulation models: full hydrodynamic, zero inertia, kinematic wave. Journal of Agricultural Science. 4(12): 68-74.

Mohammad, V. (2012b). Sprinkle and trickle irrigation system design using tapered pipes for pressure loss adjusting. Journal of Agricultural Science. 4(12): 126-133.

Morgan, L. (2006). Grow gorgeous lilies hydroponically. The Growing Edge Magazine 17(4): 36-43.
Mumpton, F.A. (1983). Natural zeolites, in: Pond, W.G., Mumpton, F.A. (Eds.), Zeo-agriculture: Use of Natural Zeolites in Agriculture and Aquaculture. Westview Press, Colorado, USA, pp. 33-43.

Nelson, D.W., Sommers, L.E. (1982). Total carbon, organic carbon, and organic matter, in: Page, A.L., Miller, R.H., Keeney, D.R. (Eds.), Methods of Soil Analysis Part 2 - chemical and microbiological properties. American Society of Agronomy, Wisconsin, USA, pp. 539-579.

Pardossi, A., Malorgio, F., Incrocci, L., Carmassi, G., Maggini, R., Massa, D., Tognoni, F. (2006). Simplified models for the water relations of soilless cultures: What they do or suggest for sustainable water use in intensive horticulture. Acta Hortic. 718: $\quad 425-\quad 434$. doi:10.17660/ActaHortic.2006.718.49

Qian, Y.L., Koski, A.J., Welton, R. (2001). Amending sand with isolite and zeolite under saline conditions: leachate composition and salt deposition. HortScience 36(4): 717-720.

Raviv, M., Krasnovski, A., Medina, S., Reuveni, R. (1998). Assessment of various control strategies for recirculation of greengreenhouse effluents under semi-arid conditions. J. Hortic. Sci. Biotech. 73: 485-491. doi:10.1080/14620316.1998.11511003

Rechcigl, J.E., Payne, G.G. (1990). Comparison of a microwave digestion system to other digestion methods for plant tissue analysis. Commun Soil Sci Plan. 21: 2209-2218. doi:10.1080/00103629009368373

Richards, L.A. (1954). Diagnosis and improvement of saline and alkali soils. USDA Agric. Handbook No. 60. U.S. Government Printing Office, Washington, DC. doi:10.1097/00010694195408000-00012

Rusan, M.J., Al-Qawasmi, W., Zuraiqi, S. (2003). Response to $K$ fertilizers by crops grown in calcareous soils in Jordan, in: Johnston, A.E. (Ed.), Potassium and Water Management in West Asia and North Africa. Proc. Regional Workshop of the International Potash Institute, Amman, Jordan, pp. 49-58.

Safi, M.I., Bulad, A., Blawenah, A. (2007)a. Flower yield and quality of Lilium aziatische irrigated with different types of water. Bulg. J. Agr. Sci. 13: 5154.

Safi, M.I., Fardous, A., Muddaber, M., El-Zuraiqi, S., Balawneh, A., Al-Hadidi, L., Bashabsheh, I. (2007)b. Long term effects of reclaimed water on rose and carnation cut flower crops in soil and soilless media. J. Appl. Sci. 7(8): 1191-1198. doi:10.3923/jas.2007.1191.1198 
Safi, M.I., Fardous, A., Muddaber, M., El-Zuraiqi, S., Al-Hadidi, L., Bashabsheh, I. (2005). Effect of treated saline water on flower yield and quality of Roses (Rosa hybrida) and Carnation (Dianthus caryophyllus). ScienceAsia 31: 335-339. doi:10.2306/scienceasia1513-1874.2005.31.335

Savvas, D. (2001). Nutritional management of gerbera (Gerbera jamesonii) grown in a closed soilless culture system. Acta Hortic. 554: 175-182. doi:10.17660/ActaHortic.2001.554.18

Savvas, D., Manos, G. (1999). Automated composition control of nutrient solution in closed soilless culture systems. J. Agr. Eng. Res. 73: 29-33. doi:10.1006/jaer.1998.0389

Savvas, D., Sigrimis, N., Chatzieustratiou, E., Paschalidis, C. (2009). Impact of a progressive $\mathrm{Na}$ and $\mathrm{Cl}$ accumulation in the root zone on pepper grown in a closed-cycle hydroponic system. Acta Hortic. 807: 451-456. doi:10.17660/actahortic.2009.807.64

Shannon, M.C. (1998). Adaptation of plants to salinity. Adv. Agron. 60: 75-119. doi:10.1016/S00652113(08)60601-X

Shannon, M.C., Grieve, C.M., 1999. Tolerance of vegetable crops to salinity. Sci. Hortic. 78: 5-38. doi:10.1016/S0304-4238(98)00189-7
Sonneveld, C. (1981). Items for application of macroelements in soilless cultures. Acta Hortic. 126: 187195.

Sonneveld, C., Van der Burg, A.M. (1991). Sodium chloride salinity in fruit vegetable crops in soilless culture. Neth. J. Agr. Sci. 39: 115-122.

Sonneveld, C., Baas, R., Nijssen, H.M.C., de Hoog, J. (1999). Salt tolerance of flower crops grown in soilless culture. J. Plant Nutr. 22(6): 1033-1048. doi:10.1080/01904169909365692

Stavros, I. Y., Gerasimos, L., Nicolaos, T., Wang, L., Mohammad, V., Aldo, T., Anderias, N. A., (2015). Evolution of water lifting devices (pumps) over the centuries worldwide. Water (7): 5031-5060. doi:10.3390/w7095031

Williams, K.A., Nelson, P.V. (1997). Using precharged zeolite as a source of potassium and phosphate in a soilless container medium during potted Chrysanthemum production. J. Am. Soc. Hortic. Sci., 122(5): 703-708.

Yasuda, H., Takuma, K., Fukuda, T., Araki, Y., Suzuka, J., Fukushima, Y. (1998). Effects of zeolite on water and salt control in soil. B. Fac. Agr., Tottori University 51: 35-42 